This item was submitted to Loughborough's Research Repository by the author.

Items in Figshare are protected by copyright, with all rights reserved, unless otherwise indicated.

\title{
Myth maker: Malcolm Bradbury and the creation of Creative Writing at UEA
}

PLEASE CITE THE PUBLISHED VERSION

http://dx.doi.org/10.1080/14790726.2016.1192196

PUBLISHER

(C) Taylor \& Francis

VERSION

AM (Accepted Manuscript)

PUBLISHER STATEMENT

This work is made available according to the conditions of the Creative Commons Attribution-NonCommercialNoDerivatives 4.0 International (CC BY-NC-ND 4.0) licence. Full details of this licence are available at: https://creativecommons.org/licenses/by-nc-nd/4.0/

\section{LICENCE}

CC BY-NC-ND 4.0

\section{REPOSITORY RECORD}

Jaillant, Lise. 2019. "Myth Maker: Malcolm Bradbury and the Creation of Creative Writing at UEA". figshare. https://hdl.handle.net/2134/21388. 


\title{
Lise Jaillant \\ Myth Maker: Malcolm Bradbury and the Creation of Creative Writing at UEA ${ }^{1}$
}

\begin{abstract}
When did creative writing courses really appear in the UK? The usual story is that the first creative writing programme was launched in 1970 at the University of East Anglia, under the leadership of Malcolm Bradbury. Ian McEwan is often presented as the first student in creative writing, a role he has always rejected - insisting that he studied for an MA in literature with the option to submit creative work for the final dissertation. As Kathryn Holeywell has shown, creative writing was already offered for assessment at UEA in the 1960s. This article tells a more complete history of creative writing in Britain, a history that takes into account the experimentations of the 1960s and the rise of literary prizes in the 1980s - without ignoring Bradbury’s important role.
\end{abstract}

KEYWORDS: Creative writing in literature courses; literary prizes; celebrity; writing communities

The story is familiar and goes something like this: in 1970, the young Ian McEwan saw an announcement for a new postgraduate course in creative writing at the University of East Anglia. He gave a call to Professor Malcolm Bradbury, sent a writing sample, and became the first (and only) student of the first MA in creative writing in the UK. McEwan, of course, went on to become one of the most successful British writers of literary fiction. And Bradbury was knighted in 2000, shortly before his death, for his services to literature.

This is a good story, which emphasises the extraordinary luck of both McEwan and Bradbury. But it is also a retrospective narrative, which obscures the fact that creative writing in Britain was not entirely new. As Kathryn Holeywell has shown, creative writing was offered for assessment at UEA in the 1960s. ${ }^{2}$ And in autumn 1969, Lancaster started offering a creative writing option for undergraduates. From 1970, students who took this option got a mark, which counted 
towards their degree. David Craig (the founder of the programme) wrote: "if we believe that creative writing deserves to be on the syllabus for its validity as an expression of the whole person and an exacting challenge to the honesty of our intelligence, then it also deserves to count, which means to be marked” (84-85). Informal courses had long existed - for example, in the 1950s, David Lodge took a course on "Essay Writing” at University College London, which included practical criticism and writing exercises (Chap. 9). Outside academia, the Arvon Foundation started offering creative writing courses to a wide range of publics as early as 1968.

It is certainly true that postgraduate courses in creative writing were unheard of in the UK. But programmes with formal supervision, within a taught creative writing MA, did not appear in 1970. As McEwan himself has repeatedly said, he studied literature with the option to submit fiction instead of a critical dissertation. ${ }^{3}$ He also had no more than a few informal meetings with Bradbury - nothing that resembled a structured writing programme. The casual nature of this supervision was far from unusual in a period when universities were less subject to regulation than they are today. But if McEwan signed up for a programme with "formal supervision in creative writing” (as the graduate handbook for 1970 promises), ${ }^{4}$ he simply did not get what he expected. "My writing life has been one long uphill struggle to persuade the world that I didn't do a creative writing course,” he once declared (qtd. in Benedictus).

When we talk about the institutionalisation of creative writing in the university system, we need to make two distinctions: was creative writing offered for assessment and accreditation? And was it formally taught (within workshops, for example) and supervised? The first stage of institutionalisation occurred in the 1960s at the undergraduate level at UEA, and later at Lancaster. The second stage seems to have happened in the early 1980s, which coincides with the creation of an MA in creative writing at Lancaster. So why do we continue to associate the origins of creative writing in Britain with a specific year (1970) - despite McEwan’s repeated declarations and despite Holeywell's account of the longer history of creative writing at UEA? And why do we continue to 
place Malcolm Bradbury at the centre of this story - even though there were many other people, at UEA, Lancaster, and elsewhere, who experimented with creative writing courses?

Bradbury contributed to shaping the founding myth of creative writing in Britain - which makes it particularly powerful and enduring. From the 1980s, he told the story repeatedly. “McEwan was in my creative writing class,” he declared in a typical 1992 interview (Gensane 45). How could McEwan be in a creative writing class that consisted of only one student? Despite the inconsistencies, the story has been influential because, arguably, it fits in a cultural model that we recognize - the model of the older writer who discovers and consecrates young talents. ${ }^{5}$

Accounts of creative writing in Britain have often been written by friends, colleagues or disciples of Bradbury, and tend to overestimate his role. Take Body of Work: 40 Years of Creative Writing at UEA, a collection of essays edited by Giles Foden and first published in draft on the website malcolmbradbury.com in 2010. Foden, who teaches at UEA, is well aware that the university had already experimented with creative writing in the 1960s. And yet, the title of the collection implicitly puts the emphasis on 1970 as the starting year for "creative writing at UEA.” Foden's introductory essay mentions Bradbury in the first paragraph and leaves little doubt as to his central role ("this organic process would probably not have happened if Bradbury had not joined the staff of UEA in 1965” [11]). A review of the book in the Guardian is illustrated with a picture of Bradbury in the classroom (Davies).

The overemphasis on a charismatic leader obscures deep institutional forces that were moving British universities towards the American model of higher education. In the wake of the Robbins Report, the new universities of the 1960s were fertile sites of experimentation, and it is not surprising that creative writing appeared at UEA and Lancaster rather than, say, Oxford. My ambition in this article is to tell a more complete history of creative writing in Britain, a history that takes into account the experimentations of the 1960s and the rise of literary prizes in the 1980s without ignoring Bradbury's important role. This article gives him credit where it is due: for his extensive knowledge of creative writing in American universities, and his willingness to adapt this 
model to the British context; for the energy he put into the promotion of the MA; and for his ability to contribute to a community - “or significant climate around writing,” as Foden notes. ${ }^{6}$ But creative writing in Britain was never a single-man enterprise. It was not until the 1980s that the discipline became so strongly associated with UEA - and this association was largely due to the rise of the whole sub-group sometimes referred to as the "university set"7 (Bradbury, but also David Lodge, Angela Carter, Maggie Gee, and former UEA students Rose Tremain, Clive Sinclair, Ian McEwan and Kazuo Ishiguro). While Bradbury's unique talents should be recognized, it is also essential to pay attention to networks that shaped creative writing in Britain.

Surprisingly, the origins of creative writing in the UK have attracted very little scholarly scrutiny. Michelene Wandor presents her book The Author is Not Dead, Merely Somewhere Else (2008) as "the first history of CW in formal, higher education in the UK" (4), but it lacks evidence from the archive. And whereas Holeywell's short article focuses on the period from 1963 to 1966, my essay has a broader timeframe, from the early 1960s to Bradbury’s death in 2000. I discovered unknown documents in the Malcolm Bradbury papers at Indiana University, various archives at UEA and the Booker Prize archive at Oxford Brookes University. I also interviewed, in person and on the phone, many people associated with the first creative writing programmes (including Ian McEwan, Victor Sage, and Jon Cook). When an interview was not possible, I sent out questionnaires and got responses from David Lodge and David Craig. These various research methods shed light on the complex history of creative writing in Britain, a history tied to the changing nature of the university system and to the emergence of opportunities for certain groups of enterprising academics and writers.

\section{Malcolm Bradbury and UEA's Mid-Atlantic Men}

Instead of presenting Malcolm Bradbury as an exceptional leader who founded the first creative writing programme in Britain and launched Ian McEwan's career, it is important to look at 
the broader picture. My point is that the characteristics that made Bradbury interested in creative writing as a discipline (including his extensive experience of the American higher education system) were shared by many of his colleagues in Norwich. I want to look at Bradbury's career within the larger context of the development of UEA, an experimental university that attracted nontraditional professors with new ideas and international experience.

Remembering his youth in the 1950s and early 1960s, Bradbury described himself as "a regular transatlantic traveller . . . a typical example of a constant figure of the time, Midatlantic Man” (Stepping Westward iii). As a nineteen-year-old student at University College Leicester, he had won a scholarship to go to Canada to research commercial radio. Two years later, in 1953, CBC (Canadian Broadcasting Corporation) broadcast his play “A Plane Out of Iceland” (“Author’s Success”). Bradbury finished his BA that year and went on to do an MA, then a two-year research degree, at Queen Mary College in London. While continuing to work on his fiction, he was writing a thesis on English little magazines of the early twentieth century. "I took up this particular topic because the whole question of whether literary magazines had any serious part to play in contemporary cultural life was at the time widely under discussion,” Bradbury later said, thus stressing his long-lasting interest in literary institutions and in the material conditions that allow artistic creation (“Critical years” 31). His research on modernist magazines gave him a chance to meet T. S. Eliot, who wrote him letters of introductions to Ezra Pound and important New Critics: Allen Tate, John Crowe Ransom and Cleanth Brooks. Towards the end of his degree, Bradbury started applying for scholarships to go to the United States to expand the scope of his project towards American little magazines. In his proposal, he mentioned his interest in New Criticism and his intention to "gain access to books, and to people" useful to his project. ${ }^{8}$ One of his former professors at Leicester, Colin J. Hornex, wrote an enthusiastic reference letter: "There is some reason to hope that Bradbury will be a writer more heard of in the future and I recommend a stay in America while he is still in his formative years."9 
Bradbury’s first year in the United States, in 1955-1956, was indeed a turning point. He was offered a teaching assistantship at Indiana University and wrote a series of articles on AngloAmerican relationships for the Guardian Journal. He described crossing the Atlantic on a luxury boat (“an opulent floating luxury hotel, with its shops, cinemas, sports and unlimited relaxation”) and meeting like-minded people, "English, American and French, participating in such exchange schemes and travelling on grants awarded by the Fulbright Act." "For all these people," wrote the young Bradbury, "the change is both exciting and momentous; they are learning in this way the new internationalism that is necessary in these times when communications between nations are essential” (“Cultural Ties in the Making”). Many things fascinated Bradbury in America - from dry-cleaners to young women. One of the most important things he learnt was that universities could be havens for writers. Taking the example of the New Critics, who "were influential teacherwriters,” Bradbury later said: "the idea that writers could work together, share techniques, learn from each other's styles, treat each other as serious practitioners, was an improvement over the British custom of isolated amateurism. I came back over the Atlantic a sceptical convert, thinking we might do better at home” (“Class Act” 36, 38). American universities offered opportunities for writers to share ideas, but also to make a living. In 1968, shortly after coming to Norwich, Bradbury wrote:

When I got to America . . . , I found at once that it was easier to be the kind of writer I wanted to be. . . .

The States wasn't only the source of some of the liveliest and most relevant arts and ideas, but also of some of the most generous financial support for them: the great grant-giving nation, the country where the writer had a place on campus, a good range of fee-paying media, and good supplementary royalties. In particular, it was easy for the writer-teacher like myself to get to the States, by teaching or on fellowships, and once there to receive every encouragement for being a writer. The explicit regard for creativity there was of the greatest importance to me, since it was virtually not to be had in England at all. But even more the States suggested to me that there was a working relationship to be made between the two things that interested me most - writing and university teaching - and that the university campus could indeed be bohemia, a place of intellectual and artistic ferment in which it was also possible to preserve a high degree of independence, economic and intellectual. (“One Man's America” 63) 
Being a writer was a "lonely amateur occupation" in Britain, but it was a professional, financially viable activity on American campuses. Bradbury’s reference to "bohemia” is of course significant for someone whose research expertise focused on modernism. While the modernists had viewed Paris, London, and, to a lesser extent, New York as centres of creativity, younger American writers increasingly favoured the Midwest and the South. At the University of Iowa, Paul Engle untiringly sought out funding for the creative writing programme. In the 1960s, sponsors included a wide range of companies and organizations, from the Northern Natural Gas Company of Omaha to the US Steel Foundation. This economic model based on a mix of private and public grants impressed the young Bradbury - even though, as we will see later, he was never as enterprising as Engle in the search for funding for UEA’s creative writing programme.

When the University of East Anglia was created in 1963, it became (along with other "plateglass” universities) a haven for academics eager to shake the traditional British university system. The first Vice Chancellor for the new university, Frank Thistlethwaite, had lived in the United States as a young man (he won a Commonwealth Fund fellowship in 1938 to study at the University of Minnesota) and had married an American woman (Sanderson, “Thistlethwaite”). Bradbury later presented Thistlethwaite as the "founding father of American Studies in Britain" who "had encouraged the university in an academic plan in which inter-disciplinary connections were central. In the arts schools, this meant primarily a link between history and literature” ("How I Invented America” 133). Thistlethwaite valued interdisciplinarity, and surrounded himself with colleagues who had first-hand experience of the American university system - including his former Cambridge classmate, Ian Watt. Between 1948 and 1962, Watt had studied at the University of California - Los Angeles and Harvard University, then taught English at UC, Berkeley. He left California to move to Norwich, becoming Dean of English Studies during the first academic year (1963-1964). As Holeywell has shown, Watt was instrumental in the hiring of Angus Wilson as the first professional writer to teach in a UK university (15). 
Watt also encouraged Nicholas Brooke, a Shakespearian scholar, to come to UEA and contribute to the development of English studies. As his former student Lorna Sage recalls, Brooke was “anti-order” and “may have been predisposed to relish insecurity, just because his family were so set in Cambridge.” The son of a distinguished professor of medieval history, Brooke started teaching at Jesus College, Cambridge, before taking up a lectureship at Durham University. Despite close friendships with some of his colleagues, "Durham was too collegiate and churchy for his tastes.” Reading Sage's portrait of Brooke, one gets the impression of a man who found his place at UEA precisely because he was an outcast in more conservative universities.

For Brooke, going to UEA in the early 1960s must have been a daring decision. Victor Sage, who was then studying at Durham with his wife Lorna, gives a sense of what UEA was like at that time:

Nicholas Brooke anyway came here, and they said to us, would you like to come here to do postgraduate work and he said: 'Oh no, don’t come this year because we haven’t got any books.' So this place was in that situation, where it was going to have to build a university library so it was not quite ready, it had no infrastructure $\ldots{ }^{10}$

The lack of infrastructure was still an issue in 1965, when Brooke offered an appointment to Malcolm Bradbury, then a lecturer at the University of Birmingham. Making decisions was never an easy thing for Bradbury, and in the archive at Indiana University I discovered two letters, both dated 18 February 1965 - one in which he accepts the position despite "family problems" and another one in which he rejects it:

After a long struggle about the decision, I’ve had to decide that I can’t really come to East Anglia just at the moment. As you know, it was, for several reasons, hard for me to weigh the matter, but yesterday we heard that my wife has to have two operations, involving a long spell in hospital, and it was for these family reasons that we decided that this was not a good time for us to move. It sounds inept to say so, but if in a year or so the developments in American literature continue, I should be most interested to be considered then. ${ }^{11}$

In addition to his wife's health problems, Bradbury had to ponder over his friends' insistence that he stay at "Brum" (the University of Birmingham). David Lodge, who was then holding a 
fellowship in the United States, wrote to him a long letter listing all the reasons why he should reject UEA’s offer:

(1) Norwich, though not as daft as Colchester, is pretty experimental and far-out, and educationally, you're a conservative. (2) in a new university the only compensation for the lack of resources, library etc is the satisfaction of shaping syllabuses, building up the strength of the department etc - is this really you? (3) I've never been to Norwich but I bet it's dead from the neck up - and down for that matter - and that most of the interesting people in the University will spend all their time in London. (4) Birmingham is one of the few provincial centres where there are opportunities for significant cultural activity, and the university has a lot of solid assets. You and I and Jim have, I think, already seen that through contact with the local theatre and the BBC - there are all kinds of possibilities for getting started a non-metropolitan spring of literary activity. The Department, when all's said and done, is a happy one as they go. ${ }^{12}$

Lodge was right to point out that UEA, a new “plate glass” university, was very different from “redbricks” such as the University of Birmingham. But he misjudged Bradbury’s ability to adapt and thrive in an "experimental” university. And, as the rest of his letter shows, he also mistakenly thought that the Norwich job would be detrimental to Bradbury’s writing:

I think it comes down to a question, which has been occupying me of late, too, and that is: is your ambition directed ultimately at success in academe or in creative writing? Of course one can combine them - as we do but sooner or later, I feel, one has to decide which is to get the lion's share of one's time and energy. If it's academe in your case, if you would like to get a Chair as soon as you possibly can, I guess the Norwich job might help; but if, as I believe, it’s writing that's your real interest, then I believe your present position at Brum is much better.

As the correspondence between Lodge and Bradbury makes clear, UEA was primarily interested in developing its offering in American studies. But creative writing had of course originated in the United States, and was already taught at UEA. Once established in Norwich, Bradbury benefited from a flexible system that allowed him to experiment with new courses, and to combine his work as a writer and as a critic. "I thought we would stay for two or three years while the university was starting but we rooted,” Bradbury later said (Collins 8). 
One reason why Bradbury fitted so well at UEA was his enthusiasm for the American university system, a system that encouraged interdisciplinarity and flexibility. At Iowa, Paul Engle stressed this ambition to cover all areas of human activity: "If it is proper to teach children chickensexing, which calls for extreme acuteness of eye, and weaving, which can be a matter of the most gracious taste in design, then why is it not appropriate to teach originality in writing?” (“The Writer and the Place” 2). The American modular course system of teaching and examining meant that a creative writing course could be added without designing an entire programme. This was really a central difference with the British system, based on extreme specialization and final-year assessment. As David Lodge puts it, "most universities examined undergraduates at the end of a three-year course exclusively by a set of three-hour written examinations, a method which obviously could not be applied to creative writing." ${ }^{13}$ From the start, UEA adopted a model close to the American system, with degree options, on-going assessments, seminar-based teaching and, from 1971, American-style writers-in-residence (with the Henfield Writing Fellows). Bradbury and Wilson also suggested the possibility of introducing a creative writing option for postgraduate students, which famously attracted Ian McEwan to Norwich.

\section{Ian McEwan and the Rise of the "UEA Clique"}

In October 2014, I attended the talk that McEwan gave at the UEA Autumn Literary Festival and the following Questions \& Answers with a group of American exchange students as well as local "MA Prose students, prose faculty and Fellows only." Predictably, someone asked a question about McEwan's experience as a student at UEA. “They claim me as the first student of creative writing," McEwan said, but "there was no course” - "We never went in his [Bradbury's] room to discuss my work." ${ }^{14}$ Archival documents show that McEwan took four modules of the MA in The Nineteenth and Twentieth-Century Novel: The Theory of Fiction; Symbolism and American Literature; The English and American Novel 1945-present; and A Comparative Study of Some 
English and European Novelists. ${ }^{15}$ The only "creative" aspect of the course was the possibility to submit creative writing instead of a critical dissertation. Although there was no workshop provision, this existing dialectic between critical and creative work would later be central to the development of the MA in Creative Writing.

A few months after McEwan’s talk, I interviewed him over the phone. When I asked him why he spent so much time at UEA (giving talks, meeting students, answering questions from researchers like me), he replied:

UEA was very good to me, it gave me the most wonderful year of my life, it started my literary career, I had its undivided attention in the form of Malcolm [Bradbury] and Angus [Wilson], I made many, many good friends there, it became an important locus of my life - and for that reason, I don’t want to turn my back on it, I owe it a great deal. It never quite was what the UEA PR machine - it never quite was what it described. There was no course ... but it wouldn’t have happened without UEA. So even though the place has changed, it's a lot more impersonal, far more students and so on, I still feel very connected. ${ }^{16}$

McEwan gives the impression that some impersonal force (“they," "the UEA PR machine”) created the myth of creative writing in Britain, casting him in the role of the first student. And he hardly exaggerates when he says that he has repeatedly tried to convince the world that he did not study creative writing.

As early as 1983, McEwan was already telling the same version of the story. The Book Marketing Council had just released the names of the 20 writers to be mentioned in its Best of Young British Novelists promotion campaign - including many writers associated one way or another with UEA (McEwan, Ishiguro, Rose Tremain, Clive Sinclair and Maggie Gee). In an article entitled “Mr Bradbury’s Finishing School,” the Guardian declared:

The very first student on the Norwich list was Ian McEwan, who has shown some resentment that he is held up as one of their successes when, as he sees it, the fiction written on the course amounted to about one sixth of his MA work, and the course itself amounted to about three drinks with Bradbury and general discussion of what he was doing. 
McEwan told the interviewer: "no one wants to see himself as the product of a course; it strikes at the mythology of individualism.” But he also recognized that his year at UEA had been “invaluable," particularly in terms of practical advice on starting a literary career ("It was very useful that Malcolm suggested some literary editors I could send stories to, that was quite marvellous”) (Hebert).

It is perhaps the ambiguity of McEwan's account - pride and gratefulness mixed with resentment - that makes it less compelling than the creative-writing-started-in-1970 story. And even if McEwan did not study creative writing per se, he benefited from an exceptionally nurturing environment at UEA. Archival documents confirm that Bradbury, Angus Wilson and Alan Burns (who held the first Henfield Writing Fellowship) took a keen interest in his work. In May 1971, Wilson wrote to Bradbury:

Alan Burns is doing splendid things - the magazine, in particular, seems to have acted as a great stimulus. ... He already speaks enthusiastically of Ian McEwan. I also admire his work greatly. I am lunching with him today to talk to him about it. ${ }^{17}$

Here, Wilson presents himself both as a fan of the young McEwan and a mentor eager to give advice over lunch. Three months later, he wrote to Alan Ross at the London Magazine and enclosed "for the interest of your editorial staff a piece written by one of my students at Norwich which seems to me to have great virtues." "To have an opinion from one of your editors," added Wilson, "if you think it at all worth encouraging would be of great service” (qtd. in Drabble 421). After graduation, Wilson helped McEwan get funding from the Arts Council. The $£ 1,000$ grant - the equivalent of an income of around £25,000 in 2015 (Officer and Williamson) - "was very important at an impoverished time” (Benedictus). When Jonathan Cape published McEwan's inaugural collection of short stories First Love, Last Rites (1975), Wilson supplied a blurb quoted in advertisements: “An important new writer . . . sensitive without shapelessness and intelligent without smart aleckry.”"18 Anthony Thwaite - the 1972 Henfield Writing Fellow at UEA - reviewed the book in the Observer: "the eight [stories] . . look as if some of the characters from early Angus 
Wilson had been painted by Francis Bacon." Nowhere in the review was it mentioned that McEwan, Wilson and Thwaite himself belonged to the same UEA network. It is a good example of what the sociologist David Morgan has called the "hidden work” in the production of culture (31): casual readers tend to think of the author as the unique producer and ignore the social relationships between the writer and other actors of the literary field.

Bradbury also provided advice and encouragement to McEwan in the years following his graduation. He sent one of McEwan’s stories to the Transatlantic Review, which paid £5 for its publication, and he brought his former student to the attention of the New American Review (Benedictus). McEwan was not, of course, the only one to benefit from Bradbury's help. In December 1973, for example, Bradbury recommended one MA student's play for the Radio Times Drama Awards Scheme. ${ }^{19}$ The student (Peter Harris) kept in touch with his mentor until at least 1975, when he told Bradbury that he had set up a writers’ workshop in Bath. ${ }^{20}$ But the link between Bradbury and McEwan proved particularly enduring. In a 1979 review in TLS, Bradbury compared Clive Sinclair’s recently-published book Hearts of Gold to McEwan’s First Love, Last Rites: “it is not an inappropriate link to make, since both McEwan and Sinclair participated in a creative writing group at the University of East Anglia” (“The Textuality of Sexuality”). ${ }^{21}$ As late as 1981 - more than ten years after McEwan's arrival in Norwich - Bradbury wrote to Peter Mayer, the CEO of Penguin Books: "I've ... got one or two young writers who took my graduate course here in Creative Writing I'd like to talk to you about. It's been a good course (most notable product is Ian McEwan).”22

McEwan's extraordinary luck was to join what became known as the "university set” at the time when this small group of writers was on the rise (with Angus Wilson a notable exception). ${ }^{23}$ In 1970, Bradbury was a well-respected professor and writer, but certainly not the bestselling author and TV personality that he would become later. When The History Man was published in 1975, it sold around 10,000 copies in hardback. When it was adapted for the BBC four years later, “10,000 turned in one night into 10 million” - Bradbury told one interviewer with characteristic 
exaggeration (Gensane 44). A search on Google Books Ngram, which shows the occurrence of selected phrases in a huge corpus of books, confirms Bradbury’s rising reputation, which continued until the late 1980s (Figure 1).

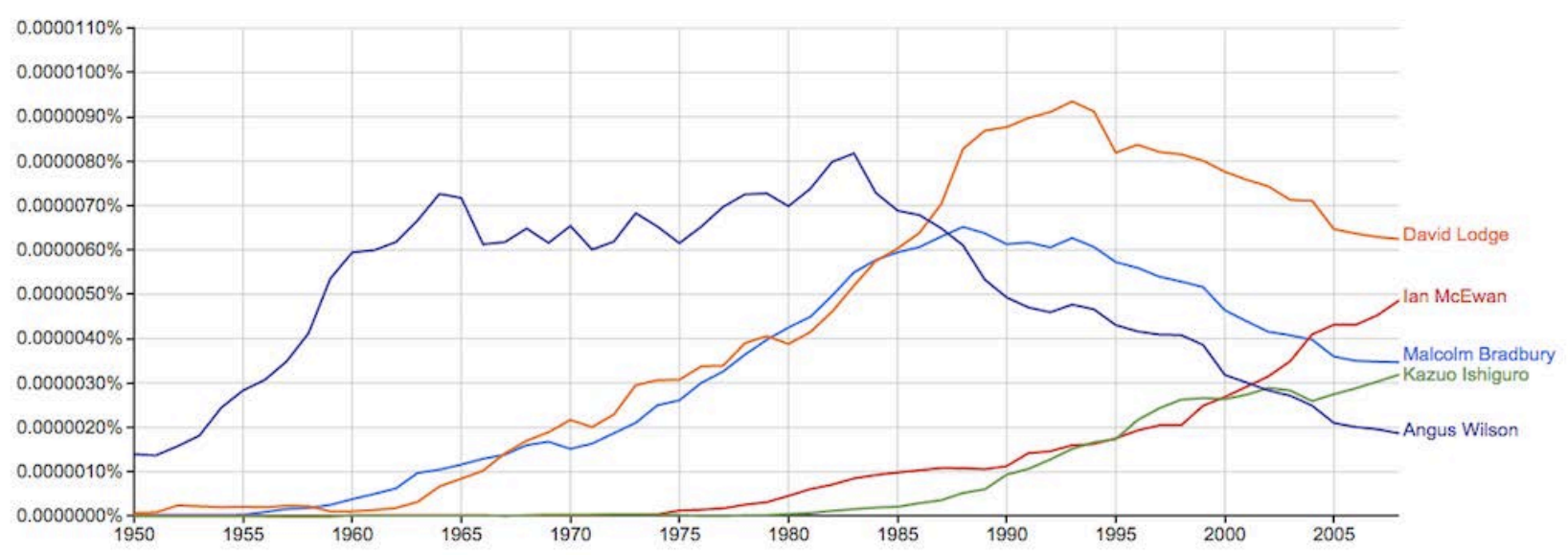

Figure 1: Graph displayed on Google Books Ngram Viewer, for the phrases "Malcolm Bradbury, Ian McEwan, Kazuo Ishiguro, David Lodge, Angus Wilson," between 1950 and 2015 from the corpus "English."

David Lodge also enjoyed increasing recognisability and commercial success. A longlasting friend of Bradbury, Lodge was asked to examine McEwan’s MA dissertation. “OK, I’ll examine your creative writing chap," Lodge wrote to Bradbury in September 1971. "It should be interesting, though rather difficult to know what kind of standard to apply. It would seem rather hard on the chap to viva him just in order to get over to Norwich to see you, but I'll bear the possibility in mind.” ${ }^{24}$ Here, Lodge pointed out an issue that remains at the centre of the discipline today: the difficulty of marking creative writing essays according to "objective” criteria. A littleknown writer in the early 1970s, Lodge later published a series of bestselling books, including the trilogy of academic novels Changing Places: A Tale of Two Campuses (1975), Small World: An Academic Romance (1984) and Nice Work (1988). He has stayed in touch with McEwan over the years (their correspondence can now be consulted at the Harry Ransom Center in Texas).

At UEA, McEwan also met several young academics who went on to distinguished careers. Jon Cook was then a fellow student, and got his first academic post in $1973^{25}$ - before climbing the professorial ladder. Like Cook, Victor Sage stayed at UEA for his entire professional career. A young English scholar who was also writing fiction, Sage met McEwan in the autumn of the MA 
year. They both published pieces in a local magazine, and saw each other several times in the spring socially. They became closer after the MA was finished, and met again in London in autumn 1971. ${ }^{26}$ "We were very interested in each other's work," McEwan declares, "so he became an important part of the writing community for me.”27 As Sage notes, McEwan was eager to meet people during his time in Norwich, and he succeeded in building strong relationships in the writing and academic worlds. In the long term, these contacts in academia helped consolidate McEwan’s place in the literary canon. As John Guillory points out, "the process of canon formation has an institutional context, the school” (45). Courses on recent British fiction often include primary texts by McEwan, as well as secondary readings such as Contemporary Critical Perspectives: Ian McEwan (Continuum, 2009), which features an interview of the writer by Sage and Cook.

In short, what McEwan gained from his year in Norwich was not primarily an education in creative writing or even mentorship by Malcolm Bradbury (“by contemporary standards, a less than model teacher" - as Peter Ho Davies puts it). What McEwan gained was access to a network of successful - or soon-to-be-successful - writers and tastemakers, within a specific institution. He was not the first student in creative writing in Britain, but he benefited from social relationships that helped him publish and promote his work (what David Morgan has called “friendship work” in relation to the production of culture [19]). And McEwan was helped by this web of distinguished writers (Bradbury, Wilson, Burns, Thwaite), fellow students (Cook) and young lecturers (Sage) because he belonged to a specific institution: the University of East Anglia. He was not an isolated would-be writer; he was already there, at the centre of an institution that would continue to rise within the larger literary field. Although McEwan never made a secret of the help he received, he has also tried to preserve his autonomy as a writer - resisting any attempt to present him as part of the “UEA clique” or as Bradbury’s protégé.

\section{The Booker Prize and the Rise of UEA's Creative Writing Programme}


In 1981, Ian McEwan's The Comfort of Strangers was shortlisted for the Booker Prize chaired that year by Malcolm Bradbury. It was the beginning of a decade of expansion for UEA's creative writing programme, after years of stagnation. Kazuo Ishiguro, who graduated in 1980, noted that the MA "hadn't run the previous year because not enough people had applied" (Hunnewell). In fact, there were five graduates in 1979, but none in 1978 (or 1972, 1976 or 1982). ${ }^{28}$ UEA presumably spent few resources to promote the programme (Ishiguro remembers coming across "almost by accident . . . a little advertisement" for the course [Hunnewell]). It took a very long time for the MA to get established, as Bradbury recognized in a report that I discovered in the UEA archives: "We were not sure it would work in Britain; we were fearful of ending up with weaker students than those elsewhere. For quite a time we were assessing its worth from year to year." ${ }^{29}$ In Autumn 1982, when Bradbury wrote the report, he found it surprising to have eight students: "The surprise comes because every single offer made was taken up, and what is more nearly every single applicant who came had very high academic qualifications.” To explain the growing attractiveness of the programme (including among American students), Bradbury mentioned the success of graduates: McEwan, Ishiguro, Clive Sinclair and Rose Tremain. The aim of the report was to convince the university's management to increase the resources allocated to the programme - for example, by hiring staff to help with the growing number of applications and to supervise dissertations during the summer term. Bradbury gave the example of Washington University in Saint Louis, which had eight faculty members and a Visiting Professor (a role he had recently taken up). Once again, when thinking about UEA’s creative writing programme, Bradbury turned towards the States for inspiration.

There was one central difference, however, between the British and the American model: funding. Harnessing America’s enterprising culture, Paul Engle had been immensely successful at raising funds for the Writers' Workshop. In the dedication to On Creative Writing, he thanked the "heartening variety of individuals, foundations, and corporations" that "have given funds to the Program in Creative Writing at the University of Iowa, so that young writers from all regions of the 
USA and many areas of the earth could come here and make an international community of the imagination” (vii). In contrast, Bradbury admitted in his report that his fundraising activities had brought few results:

I have at various times attempted to raise the money for this in other ways: from the Arts Council, from specific publishers, from Booker McConnell, the donors of the Booker Prize, etc... I have had much moral support but no guaranteed cash. I suspect a systematic attempt to trawl several publishers would be one way of doing it, but this would take time. And in my view it is in the end a Registry job.

Of course, Bradbury was working in under-staffed conditions very different from his American colleagues: he was excepted to teach (albeit part-time), deal with admissions and with the administration of the creative writing programme, while continuing his multiple activities: writing fiction, giving talks, travelling to far-away locations for the British Council. But the fact remains that unlike Engle, Bradbury did not see fundraising as one of his priorities. It is significant, because it meant that UEA attracted mostly students who could get a government grant (Ian McEwan, Kazuo Ishiguro) or who came from well-off families. Ironically, while the young Bradbury had benefited from fellowships to study on American campuses, he made little consistent effort to create similar conditions for his own students.

Bradbury's strengths lay in his vision for the creative writing programme, and in his extensive network of contacts. In his 1982 report, he recommended that "an undergraduate course in Creative Writing should be systematically provided," citing the example of Washington University in Saint Louis. Bradbury rightly anticipated the growing appeal of the discipline among all students - at the time when Minors and Majors in creative writing were becoming increasingly popular in American universities. ${ }^{30}$

At the beginning of the 1980s, Bradbury was also a well-known, well-connected writer who often used his position in the literary field to help his former students and colleagues. Analysing the creation of literary value in the marketplace, Pascale Casanova points out the importance of the name of the writer who consecrates a more junior colleague: 
Value in the literary world is directly related to belief. When a writer becomes known, when his name has acquired value in the literary market - which is to say, once it is believed that what he has written has literary value, once he has gained acceptance as a writer - then credit is given to him. Credit . . . is the power and authority granted to a writer by virtue of the belief that he has earned his "name.” (16-17)

Bradbury repeatedly used his name and authority to push writers associated with UEA. In the speech he gave as Chair of the Booker Prize in 1981, he mentioned McEwan and Angela Carter among those "who have shifted the novel sharply away from the median realism and provincialism that was so influential in the 1950s, toward largeness, moral strangeness, fantasy and grotesquerie.” ${ }^{31}$ Bradbury’s activism to promote his literary circle did not go unnoticed. For example, the satirical magazine Private Eye argued that The Comfort of Strangers was on the shortlist only because of McEwan's connection with UEA (qtd. in Lee). Shortly after chairing the Booker Prize, Bradbury actively helped another former student, the twenty-seven-year-old Ishiguro, get media attention for his first novel. A poster for a discussion between Ishiguro and Bradbury at the ICA (Institute of Contemporary Arts) in London describes A Pale View of Hills as "an extraordinary first novel, by a young Japanese writer of exceptional talent, which brings the sorrows of war-torn Nagasaki to the depths of the English countryside” (Figure 2). Follows a blurb by Angela Carter, who was Ishiguro’s instructor at UEA and who introduced him to the literary agent Deborah Rogers (he remained her client for 34 years, until her death in 2014). ${ }^{32}$ As the recording of the ICA event shows, Bradbury promoted the MA in creative writing while celebrating his former student's success. "Like Ian McEwan and Clive Sinclair," said Bradbury, "he was one of what proved to be an incredible group of writers who came to that course - brilliant to start with - and had a chance to write through a year." 33 During the interview, when Ishiguro said he did not read enough to be influenced by other writers, Bradbury adopted a professorial tone to stress that the young man had been encouraged to read widely while at UEA. In short, Bradbury kept reminding audiences that Ishiguro was his former student, a brilliant product of a brilliant course (the 
Guardian later compared him and Angela Carter to "proud parents" "zealously" defending the young writer [Targett]).

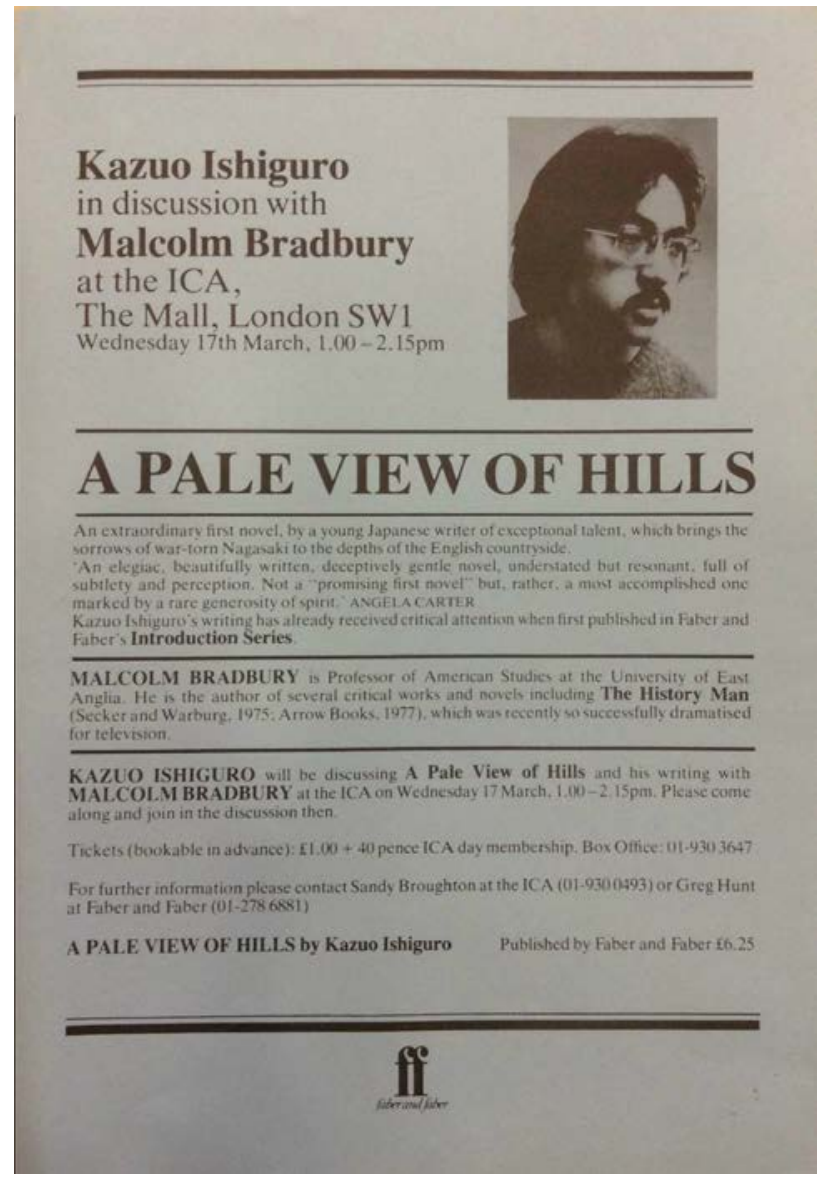

Figure 2: Kazuo Ishiguro, Interview by Malcolm Bradbury, ICA, London, 17 March 1982, Poster.

Box 48, Folder Interview with Bradbury, Bradbury M. mss. III, 1950-2000. Courtesy Lilly Library, Indiana University, Bloomington, Indiana.

Ishiguro was also among the "Best of Young British Novelists" chosen in summer 1982 (the promotional campaign started a few months later, in early 1983). There is evidence to show that Bradbury had close ties with the Book Marketing Council, which organized the campaign. In February 1983, Desmond Clarke, the Director of the Council, sent him the press pack that had been distributed to media contacts, and told him: "My target is to sell at least 250,000 copies of their books during the period of the promotion.”34 The project certainly attracted a lot of media interest, on both sides of the Atlantic. According to the New York Times, "more than 2,500 booksellers participated in the campaign, and the Book Marketing Council reports that sales of the books of the writers mentioned increased by 328 percent during the campaign” (Kakutani). The initiative helped 
raise the profile of UEA's creative writing programme (which was mentioned repeatedly in the press pack), leading to increased enrolments in the following years.

The growing visibility of the programme is also intertwined with the rise of the Booker Prize. Both institutions originated in the 1960s and shared the same ambition to promote literary fiction to a large audience. Bradbury compared the "slow process" that led to the establishment of the Booker as a major prize to the similar difficulties encountered by the UEA programme in the 1970s:

\footnotetext{
We were lucky to have Ian McEwan right at the beginning, but during the Seventies it poddled along and it was only at the end of that decade that things looked up and there was an obvious new mood. The same was true for the Booker. Initially, I think it was the stature of judges like Saul Bellow and Stephen Spender which attracted interest rather than the prize winners.

It really took about 10 years for the Booker to take off. By then, you could almost feel the stakes rising and you could also feel a new generation of writers surging into the limelight. (Snelling)
}

Ishiguro was part of this "new generation of writers" who benefited from the rise of these two institutions, UEA's creative writing programme and the Booker Prize. His second novel, An Artist of the Floating World, was shortlisted for the prize in 1986. It led to such an increase in media interest that Ishiguro had to cut himself from all distractions to write his next book. ("How I Wrote”). The Remains of the Day won the Booker in 1989, an award that was often presented as the victory of an institution, UEA. As one commentator put it, "the Ishiguro victory is an endorsement for Professor Malcolm Bradbury, who launched the school of creative writing at East Anglia University” (Radford). Bradbury presided over the Book Trust panel, which chose the judges including Maggie Gee and Helen McNeil, who both had a close association with UEA. ${ }^{35}$ Rose Tremain was also among the contenders. Suspicions of cronyism were exacerbated by the fact that Bradbury’s friend David Lodge served as chairman of the judges. But far from tarnishing the image of Bradbury and his creative writing programme, the controversy helped present UEA as the antechamber for literary success. A report held in the Booker Prize archive shows that the 1989 
award to The Remains of the Day added an additional 50,000 copies in hardback and an estimated 150,000 copies in paperback. ${ }^{36}$ "In reviews and anthologies,” wrote the Sunday Times, "Bradbury has promoted several of his most promising pupils and friends, helping to turn them into literary stars” (Palmer). A graph (Figure 3) presented Bradbury as a Godfather at the centre of "the University of East Anglia mafia,” a term which suggested illicit deals and oppositions to other gangs (including “the Granta set” and "the Telegraph clique”).

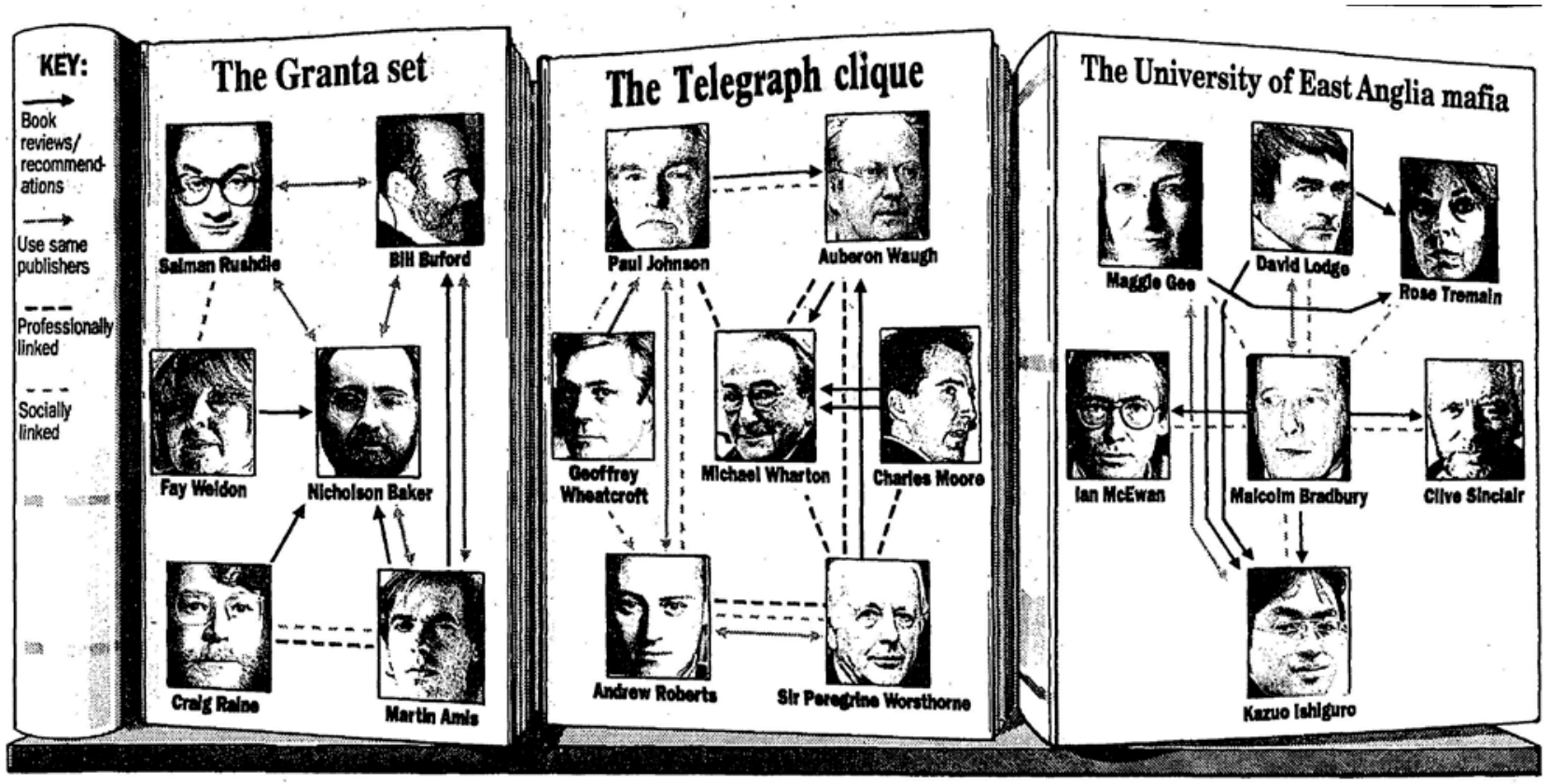

Figure 3: Graph representing "the University of East Anglia mafia” and other literary groups (Palmer)

As I have argued in this article, Bradbury did not single-handedly turn his students into literary celebrities. His activities should be viewed in a broader institutional context. What McEwan had called "the UEA PR machine” proved remarkably efficient at promoting the creative writing programme in the 1980s. In particular, archival documents show that Michael Benson, the university’s Information Officer, consistently associated the 1989 Booker Prize award with UEA, where Ishiguro had studied nearly a decade before. He nudged Bradbury to write an article on Ishiguro, ${ }^{37}$ and in an interview with the Eastern Daily Press, he said that the award "underlines the excellence of our creative writing programme, which the university has run for the past 25 years.”38 
Interestingly, Benson traced the origins of creative writing at UEA back to the 1960s. At that time, the myth of 1970 as the starting point of the programme had not yet been firmly established.

Ishiguro’s consecration was announced in October 1989 and that same month, UEA organized a seminar on "Literary Prizes and Literary Culture" to mark the twentieth anniversary of the Booker Prize. ${ }^{39}$ Since Ishiguro had been a favourite for months before the announcement of the prize ("Books and the Booker"), the timing of the seminar was hardly coincidental. Even if he had not won the prize (a distinct possibility, with heavyweight contenders such as Margaret Atwood), UEA could still celebrate the shortlisting of two alumni. The seminar was hosted by the newlycreated Centre for Creative and Performing Arts, which helped with the running of the MA and PhD in creative writing. By the late 1980s, UEA had reached a level of institutional selfconsciousness that produced a discourse celebrating the creative writing programme and associating it with other successful literary institutions such as the Booker Prize.

Economists talk of "path dependency” when, once a choice has been made and a way has been chosen, it is thought more efficient to continue along the already set path rather than reassess the various options. As Benson's discourse shows, one path would have been to celebrate the fact that creative writing was taught at UEA in the 1960s. The other path was to privilege 1970 as the starting date, with Ian McEwan as the first student. In his 2002 History of the University of East Anglia Norwich, Michael Sanderson wrote that the MA in creative writing "started in 1970 with a single student, Ian McEwan, a Sussex graduate. His extraordinary success in that year and subsequently helped to kick-start the new course, accepted in the University and of ever increasing reputation at large” (90). It is certainly true that McEwan became a successful writer at a young age, helped by Wilson, Bradbury and others. But there was no guarantee that the 1970 myth would be the best to promote UEA, since it privileged one student over others such as Rose Tremain who had studied there in the 1960s. ${ }^{40}$ So why was it chosen? One possible answer is that the aging Bradbury increasingly saw the MA programme as one of his most important achievements. Whereas creative 
writing was taught to UEA's undergraduates when he was still at the University of Birmingham, he had undoubtedly shaped the postgraduate programme. As Tremain told him, "the course is so much yours and whoever takes over from you is going to have a difficult time." ${ }^{41}$ Although Bradbury gave credit to Angus Wilson, he also placed himself at the centre of the 1970 myth ("McEwan was in my creative writing class”). When he died in 2000, the title of his obituary in the Economist was “The Creative-Writing Man” as if his main claim to posterity was the creation of the UEA programme and the “discovery” of McEwan in 1970.

\section{Works Cited}

“Author’s Success.” Evening Post 27 Nov. 1953: n. pag. Print.

Benedictus, Leo. “The Write Stuff.” Prospect Magazine 15 Dec. 2010. Web. 25 Aug. 2015.

“Books and the Booker.” Washington Post 6 Aug. 1989: J15. Print.

Bradbury, Malcolm. “Critical Years: Some Thoughts on Brian Cox and CQ.” Critical Quarterly 35.4 (1993): 31-35. Print.

---. “Cultural Ties in the Making.” Guardian Journal 18 Oct. 1955: 4. Print.

---. “How I Invented America.” Journal of American Studies 14.1 (1980): 115-135. Print.

---. “One Man’s America.” The Author 2 (1968): 61-65. Print.

---. Stepping Westward. London: Picador, 1965. Print.

---. “The Textuality of Sexuality.” Times Literary Supplement 14 Dec. 1979: 114. Print.

Casanova, Pascale. The World Republic of Letters. Trans. M. B. DeBevoise. Cambridge, Mass.: Harvard UP, 2004. Print.

"Class Act: Malcolm Bradbury Looks Back on His 25 Years as Head of a Creative Writing Course.” Telegraph Magazine 7 Oct. 1995: 34-41. Print.

Collins, Ian. “Active and Far from Retiring.” Eastern Daily Press 16 May 1998: 6-8. Print.

Craig, David. “Creative Writing at Lancaster.” Critical Quarterly 26.4 (1984): 81-85. Wiley Online Library. Web. 5 Nov. 2015.

Davies, Peter Ho. "Review of Body of Work: 40 Years of Creative Writing at UEA, Edited by Giles Foden.” Guardian 22 Jan. 2012. Web. 25 Aug. 2015.

Drabble, Margaret. Angus Wilson: A Biography. London: Secker \& Warburg, 1995. Print.

Engle, Paul. On Creative Writing. New York: Dutton, 1964. Print. 
---. “The Writer and the Place.” Midland: Twenty-Five Years of Fiction and Poetry Selected from the Writing Workshops of the State University of Iowa. Ed. Paul Engle. New York: Random House, 1961. 1-10. Print.

Fenza, David. “A Brief History of AWP.” Association of Writers \& Writing Programs. 2011. Web. 3 Feb. 2012.

Foden, Giles, ed. Body of Work: 40 Years of Creative Writing at UEA. Woodbridge: Full Circle, 2012. Print.

Gensane, B., G. Menegaldo, and R. Shusterman. “An Interview with Malcolm Bradbury, Oct. 1992.” European English Messenger 2.1 (1993): 39-45. Print.

Guillory, John. “Canon, Syllabus, List: A Note on the Pedagogic Imaginary.” Transition 52 (1991): 36-54. Print.

Hebert, Hugh. “Mr Bradbury’s Finishing School.” Guardian 28 Feb. 1983: 11. Print.

Holeywell, Kathryn. "The Origins of a Creative Writing Programme at the University of East Anglia, 1963-1966.” New Writing 6.1 (2009): 15-24. Print.

Hunnewell, Susannah. "Kazuo Ishiguro, The Art of Fiction No. 196.” Paris Review Spring 2008. Web. 27 Aug. 2015.

Ishiguro, Kazuo. "How I Wrote The Remains of the Day in Four Weeks.” Guardian 6 Dec. 2014. Web. 28 Aug. 2015.

Kakutani, Michiko. “Novelists Are News Again.” New York Times 14 Aug. 1983: BR3. Print.

Lee, Hermione. “The Booker Prize: Matters of Judgement.” Times Literary Supplement 30 Oct. 1981: 1268. Print.

Lodge, David. Quite a Good Time to Be Born: A Memoir, 1935-1975. London: Harvill Secker, 2015. Ebook.

McKay, Sinclair. “I’ll Scratch Your Hardback... If You’ll Scratch My Paperback.” Mail on Sunday 29 Oct. 1989: 9. Print.

Morgan, David. “Cultural Work and Friendship Work: The Case of 'Bloomsbury.”” Media, Culture \& Society 4.1 (1982): 19-32. Print.

Neill, Rosemary. “When Everyone’s an Author.” Australian 9 Feb. 2008. Web. 25 Aug. 2015.

Officer, Lawrence H., and Samuel H. Williamson. "Purchasing Power of British Pounds from 1270 to Present.” MeasuringWorth. 2015. Web. 26 Aug. 2015.

Palmer, Richard. “You Scratch My Book: Lit Crit’s Cosy Little World.” Sunday Times 17 May 1992: 7. Print.

Radford, Tim. “Booker Goes to Ishiguro’s ‘Beautifully Paced’ Novel.” Guardian 27 Oct. 1989: 24. Print. 
Sage, Lorna. “Obituary: Professor Nicholas Brooke.” Independent 10 Nov. 1998. Web. 26 Aug. 2015.

Sanderson, Michael. The History of the University of East Anglia, Norwich. London: Hambledon and London, 2002. Print.

---. “Thistlethwaite, Frank (1915-2003).” Oxford Dictionary of National Biography. Web. 16 Aug. 2015.

Snelling, Steve. “Making a Drama out of the Booker.” Eastern Daily Press 23 Oct. 1998: 32. Print. Targett, Jocelyn. “A Writer of the Floating Word.” Guardian 13-14 May 1989: 6-7. Print.

Taylor, D. J. A Vain Conceit: British Fiction in the 1980s. London: Bloomsbury, 1989. Print.

“The Creative-Writing Man.” Economist 2 Dec. 2000: 41. Print.

Thwaite, Anthony. “Brilliant Performance.” Observer 4 May 1975: 28. Print.

Trewin, Ion. “Deborah Rogers Obituary.” Guardian 4 May 2014. Web. 27 Aug. 2015.

Wandor, Michelene. The Author Is Not Dead, Merely Somewhere Else: Creative Writing Reconceived. Basingstoke: Palgrave Macmillan, 2008. Print.

\footnotetext{
${ }^{1}$ The research for this article was funded by the Malcolm Bradbury Memorial Trust Fund and an Everett Helm Visiting Fellowship at the Lilly Library (Indiana University). I am grateful to Andrew Cowan, Giles Foden and the anonymous reader for their feedback on earlier versions of this article. Justine Mann and Bridget Gillies have also helped me unearth interesting materials in the UEA Archives.

2 "Evidence that [Angus] Wilson offered informal creative writing instruction at UEA as early as 1963 as well as the revelation that he utilised creative writing for the assessment of at least one academic course in the School of English proves that creative writing at UEA has a much longer history than has previously been suggested” (Holeywell 21-22). ${ }^{3}$ See Benedictus and Hebert for examples.

4 "In some years it will be possible to take an M.A. in Creative Writing. This will consist of three courses taken from programme 1 (The Nineteenth and Twentieth Century Novel), including the compulsory 'The Theory of Fiction.' In addition there will be formal supervision in creative writing. A body of fiction (several short stories or part of a novel) will be substituted for the dissertation.” “The Graduate Programme,” 27 Nov. 1970, UEA/BRAD/11, UEA Collection: Malcolm Bradbury, University of East Anglia.

${ }^{5}$ The story has even crossed borders. Writing about the institutionalization of creative writing at the University of Sydney, the Australian mentioned the "postgraduate writing course” that McEwan took in Britain (Neill).

${ }^{6}$ Foden, Email to author, 5 Oct. 2015.

${ }^{7}$ See D. J. Taylor's A Vain Conceit: British Fiction in the 1980s (qtd in McKay).

${ }^{8}$ Bradbury, “Curriculum Vitae,” c. 1954, box 32, folder Indiana U. Misc., Bradbury M. mss. II, Lilly Library, Indiana University, Bloomington (hereafter referred to as “Indiana”).

${ }^{9}$ Hornex, “Mr Malcolm S. Bradbury,” 29 Dec. 1954, box 32, folder Indiana U. Misc., Bradbury M. mss. II, Indiana.

${ }^{10}$ Victor Sage, Personal interview, 27 Oct. 2014.

${ }^{11}$ Bradbury to Brooke, 18 Feb. 1965, Box 2, Folder 1965, Jan. - Feb., Bradbury M. mss. II, Indiana. I am grateful to Dominic Bradbury for permission to reproduce this letter.
} 
${ }^{12}$ Lodge to Bradbury, 12 Feb. 1965, Box 7, Folder Correspondence Lodge 1962-1968, Bradbury M. mss. II, Indiana.

${ }^{13}$ Lodge, Questionnaire returned to author in June 2015.

${ }^{14}$ McEwan, Questions and Answers, 22 Oct. 2014.

${ }^{15} \mathrm{UEA} / \mathrm{BRAD} / 11$.

${ }^{16}$ McEwan, Telephone interview, 9 March 2015 (emphasis added).

${ }^{17}$ Wilson to Bradbury, 25 May 1971, Box 7, Folder Correspondence W-Z, Bradbury M. mss. II, Indiana.

${ }^{18}$ Times Literary Supplement 28 March 1975: 328.

${ }^{19}$ Bradbury to Radio Times, 17 Dec. 1973, LIT/CW/4, Archives of Modern Writing and Literary Translation (hereafter referred to as AMWLT), UEA.

${ }^{20}$ Harris to Bradbury, 7 Sept. 1975, LIT/CW/4, AMWT, UEA.

${ }^{21}$ Sinclair did not study for the MA in creative writing (he did a BA at UEA, graduating in 1969, and then came back as a PhD student).

${ }^{22}$ Bradbury to Mayer, 6 Feb. 1981, Box 4, Folder Correspondence 1981 Jan.-May, Bradbury M. mss. II, Indiana.

${ }^{23}$ Victor Sage attributes the eclipse of Angus Wilson's reputation to his close affiliation with social realism, a genre in decline from the 1970s. Personal interview, 27 Oct. 2014.

${ }^{24}$ Lodge to Bradbury, 11 Sept. 1971, Box 7, Folder Correspondence Lodge 1969-1994, Bradbury M. mss. II, Indiana.

${ }^{25}$ Cook, Personal interview, 6 Oct. 2014.

${ }^{26}$ Sage, Email to author, 17 March 2015.

${ }^{27}$ McEwan, Telephone interview, 9 March 2015.

${ }^{28}$ Thanks to Andrew Cowan for this information.

${ }^{29}$ Bradbury to “Roger," 11 Oct. 1982, LIT/CW/9, AMWLT, UEA.

${ }^{30}$ According to the Association of Writers and Writing Programs, in 1975, there were 24 higher education institutions offering Minors in creative writing and 3 offering Majors in creative writing for undergraduate students in the USA. These numbers rose to 155 and 10 respectively in 1984, reaching 347 and 157 respectively in 2010 (Fenza).

${ }^{31}$ Bradbury, “The Booker Prize Speech,” 20 Oct. 1981, BP/1/13/1/2: Administrative Papers, 1981, Papers of the Booker Literary Prizes, Oxford Brookes University.

${ }^{32}$ See Hunnewell and Trewin.

${ }^{33}$ Kazuo Ishiguro, Interview by Malcolm Bradbury, ICA, London, 17 March 1982, Audio Recording, British Library Sounds, Web. 27 Aug. 2015, <http://sounds.bl.uk/Arts-literature-and-performance/ICA-talks/024M-C0095X0015XX0200V0>.

${ }^{34}$ Clarke to Bradbury, 10 Feb. 1983, Box 48, Folder Best of British Authors and Publicity, Bradbury M. mss. III, 19502000, Indiana.

${ }^{35}$ Gee held a Writing Fellowship in 1982 and McNeil was then working as Lecturer in American Studies at UEA.

${ }^{36}$ Andrew Thompson to Christina Shaw, c. 1990, BP/1/21/1/2: Administrative Papers, 1989, Papers of the Booker Literary Prizes, Oxford Brookes University.

${ }^{37}$ Benson to Bradbury, [c. Oct. 1989], LIT/CW/6, AMWLT, UEA.

38 “UEA Delight at Booker Prize Result,” Eastern Daily Press [Oct. 1989], LIT/CW/6, AMWLT, UEA.

${ }^{39}$ Centre for Creative and Performative Arts, "Newsletter: A Celebration of Writing, Twenty Years of the MA in Creative Writing at the University of East Anglia,” 9-11 Nov. 1990, LIT/CW/13, AMWLT, UEA.

${ }^{40}$ Tremain was often thought to have studied creative writing in 1970, which shows once again the appeal of the myth. See her letter to Bradbury, 9 Feb. 1993, Box 37, Bradbury M. mss. III, 1950-2000, Indiana: "If I had still been a student 
at UEA in 1970 (as the press would have me be) I would have applied to do the course and possibly started writing reasonably good novels long before I did” (emphasis in original).

${ }^{41}$ Tremain to Bradbury, 9 Feb. 1993, Box 37, Bradbury M. mss. III, 1950-2000, Indiana (emphasis in original). 